\title{
TEKA: A Transnational Network of Esperanto-Speaking Physicians
}

\author{
Marcel Koschek \\ University of St Andrews \\ mk314@st-andrews.ac.uk
}

The Tutmonda Esperanta Kuracista Asocio (Worldwide Esperanto Medical Association, TEKA) was founded in 1908 at the Fourth International Esperanto Congress in Dresden and was the international medical association of the Esperanto movement. The aim was to "facilitate practical relations between Esperanto-speaking doctors of all countries." The interest within the Esperanto movement was immense: after one year, TEKA had more than 400 members all over the world with a focus on Europe; one year later, there were more than 600 members with official representatives in about 100 cities. In Europe, a medical press in Esperanto had already been established. The approach of these journals was both simple and brilliant: the doctors presented the latest medical findings from their home countries in a peer review system and critically examined the articles in their vernacular. This made each issue a compendium of the most important and pioneering findings of national research. The numerous experts also had many other connections with, for example, the Red Cross and similar organizations. Thus, after a short period of time, TEKA brought together the expertise of countless physicians. This paper examines TEKA as a transnational network of experts before World War I. The history of the association and the role of Medicine within the Esperanto movement are briefly discussed. The focus is then on the various association journals and the circulation of knowledge. Finally, the essay offers a look at TEKA's cooperative endeavors with the Red Cross. It works from a transnational perspective and takes a close view of the actors and their personal backgrounds at appropriate points. Furthermore, lists of members and journal subscribers are provided in map form to make the global spread of the movement within medicine visible.

Keywords: Esperanto, transnationalism, internationalism, network of physicians

\section{Introduction}

The end of the long nineteenth century was a dynamic time during which groundbreaking changes were taking place in all areas of life. The decades before World War I were characterized by networking and internationalization as well as inventions and technical progress. ${ }^{1}$ Even in medicine, the peak of internationalism

1 The following volume can serve as an introduction and overview of the internationalization of many areas of the time: Geyer and Paulmann, The Mechanics of Internationalism. The idea of an international 
did not pass without leaving its mark. In 1863, the Red Cross was founded, and in 1881, medical assembly began with the first International Medical Congress in London. At the time, Ludwik Lejzer Zamenhof, an ophthalmologist in Warsaw, also had thoughts on medicine, internationalization, and networking. In 1887, he published a brochure entitled International Language. ${ }^{2}$ This booklet, which he published under the pseudonym Dr. Esperanto (literally meaning, "the one who hopes"), joined the list of numerous inventive and stirring writings of this period. With his idea of devising a simplified language, Zamenhof presented a solution to the problem of communication; his pseudonym quickly became the name for the language itself. Esperanto harmonized with the prevailing zeitgeist among educated elites, who soon began to gather internationally and develop platforms for exchange. The language quickly gained a foothold in medicine, as outbreaks of cholera and typhus and new fields such as bacteriology led to a strong need for exchange in the medical community. ${ }^{3}$

The majority of Esperantists in the early period before World War I came from urban middle classes, which "had the money and leisure to look beyond their own communities." ${ }^{\prime}$ The exact proportion of physicians among the club members is very difficult to determine. For example, the address book of Polish Esperantists from 1909 provides lists of members but only incomplete professional information. Large university cities such as Lviv (15.6 percent), Warsaw (11.4 percent) and Krakow (6.3 percent) had the highest proportions of physicians among their members. In contrast, rural Esperanto societies only rarely had doctors among their members. ${ }^{5}$ Nevertheless, the Esperanto doctors hoped that international cooperation with foreign colleagues would foster valuable exchange and progress. One of the arguments for learning Esperanto was the simplicity of the language and the claim that the vocabulary was "threequarters known to anyone halfway educated." The 1933 Encyclopaedia of Esperanto lists early mentions of the language in medical journals. These mentions include

\footnotetext{
language also emerged at the time, in particular Volapük from 1880 and the Esperanto descendant Ido from 1907. On science and language around 1900, see: Gordin, Scientific Babel. On the competing artificial languages: Garvía, Esperanto and Its Rivals.

2 Zamenhof, International Language.

3 Medical internationalism developed particularly in connection with the pandemics of the nineteenth century. This movement of sorts initially urged the fight against the new diseases at international sanitary congresses and led to the institutionalization of the Medical Society. Huber, "Pandemics," 394-407.

4 Tonkin, "Invented cities," 92.

5 Brzostowski, Adresaro.

6 Rosenberg, "Internationalismus," 203. All translations are made by the author.
} 
a series of articles in the Russian journal V rach in 1899 and, from 1900, primarily mentions in French journals. There were also discussions concerning Esperanto at two medical meetings in Russia in 1898 in Borisoglebsk and Voronezh. ${ }^{7}$

As the language spread internationally and was propagated by and among physicians, there were both positive and negative reactions. The example of The British Medical Journal can even be used to show a shift. In 1904, the language was described as a "body without a soul," ${ }^{\prime}$ and in 1906, it was characterized as useless, since "when learnt nothing has been acquired but a mixed 'pigeon' jargon." In later years, the journal devoted more lines to the Esperanto movement. The report on the International Medical Congress in Budapest in 1909 contains a separate paragraph on the attempt to introduce the language. Although the author of the report writes with praise on the number of participants at the meeting of Esperantists, he notes that the group did not arouse any further interest among other participants. Furthermore, he also states that the need for a new language was not felt at the congress. ${ }^{10}$ The journal also gave space to the following International Medical Congress in London in 1913. The dates of the meetings were announced before the congress, and a report on the meeting was published afterwards. ${ }^{11}$ In contrast to Budapest, the London Esperanto Club held a reception which was not only attended by Esperantists but also attracted other congress participants. ${ }^{12}$ Other large, internationally prominent medical journals such as The Lancet also printed submissions on the subject of Esperanto from 1905 onwards and abstained from making any critical remarks concerning the language that might have resembled the remarks found in The British Medical Journal. ${ }^{13}$

The Esperanto movement took a big step towards international cooperation in 1905 when it held its first World Congress in Boulogne-sur-Mer. After principles of the language and the movement were discussed in Boulogne, expert meetings were held at the congresses from 1906 onwards. At the second World Congress, Henri Dor, who later served as TEKA president, chaired the joint session of physicians and pharmacists. The discussion centered on an anatomical

\footnotetext{
Sirjaev, "Medicino," 364-65.

"An International Language," 321.

"The International Medical Congress," 34.

"The Sixteenth International Congress of Medicine," 888.

"Seventeenth International Medical Congress," 263.

"Esperanto," 427.

Whitaker, "An Esperanto Society for Men," 1292.
} 
dictionary compiled by a group of French Esperantists. ${ }^{14}$ In 1907, during the congress in Cambridge, the doctors were already meeting separately. There, the assembled doctors decided to join the Internacia Scienca Asocio (International Science Association), an Esperanto science society founded the previous year, as a specialist section. A proposal was made to contact an existing multilingual medical journal and request that it publish an Esperanto supplement. ${ }^{15}$ The following congress in Dresden in 1908 led to the founding of TEKA.

\section{The Creation and Development of TEKA}

The institutionalization and organized unification of Esperanto physicians were achieved with the founding of TEKA. In TEKA's self-portrayal, the Polish doctor Wilhelm Róbin ${ }^{16}$ is often listed as the initiator and founding father. ${ }^{17}$ The reason for this was his article published in Voco de Kuracistoj ${ }^{18}$ (Voice of Physicians, henceforth $V d K)$ calling for the foundation of an Esperanto Medical Society before the World Congress in Dresden. ${ }^{19}$ However, Róbin was not present at the congress and Leon Zamenhof took over the presentation of the project there. ${ }^{20}$ The fact that the idea came from Róbin is not mentioned in the minutes of the Dresden congress. Furthermore, it must also be pointed out that Róbin was not the first Esperantist with the idea of founding an Esperanto Medical Society. This idea had already been advocated by Bronisław Skałkowski, Szczepan Mikołajski, and Izrael Fels in an appeal in the Polish Medical journal Gtos Lekaray (Voice of Physicians, henceforth GL) in November 1907. ${ }^{21}$ Whether Róbin was aware

14 Dua Universala Kongreso de Esperanto, 111-12.

15 Tria Universala Kongreso de Esperanto, 125-26.

16 Wilhelm Róbin was a committed Esperantist since the establishment of the first Esperanto circle in Warsaw in 1893. There, he was engaged as secretary of the Polish Esperanto Association and official delegate of the Universal Esperanto Association (UEA) for Warsaw. At the international level, he participated in the World Congresses in Cambridge (1907) and Krakow (1912), as well as the International Medical Congress in Budapest 1909 and the UEA Congress in Augsburg in 1910. In addition to his TEKA involvement as secretary, he wrote other articles for $V d K$ and later became editor of the periodical Kuracisto. Like many other Warsaw TEKA members, Róbin worked in the Jewish Hospital in Czyste as a gastrologist. During the interwar period, he was the first president of the Polish physicians association and vice president of Polish gastrologist association. Golec, Stownik, 185-87.

17 Dor, "Al Sinjoro," 10.

18 For technical reasons of the printing house, the first volume was published without a circumflex under the name "Vocho de Kuracistoj."

19 Róbin, "Organizo de kuracistoj-esperantistoj," 63-64.

20 Zamenhof, "Kuracistoj," 145-48.

21 Skałkowski, Fels, Mikołajski, “Odezwa do Lekarzy Esperantystów,” 4-5. 
of this appeal is not known. This is also contradicted by the fact that his name is not found among the subscribers to GL in 1907. Although the first appeal in GL did not lead to the founding of TEKA, the goals were consistent. The authors identified the first and most important task as the foundation of an association of Esperanto physicians in all countries. This association should represent the interests of their members at international medical congresses and advocate the introduction of Esperanto as a congress language. The creation of an international organ for the worldwide members was also planned. At the end of the appeal, it was noted that it should be sent to all the doctors listed in the Tutmonda Jarlibro Esperantista 1907 (Worldwide Esperantist Yearbook). Furthermore, everyone should forward this appeal and publish it in their native languages in national journals. ${ }^{22}$ We do not actually know the extent to which this suggestion was actually implemented or the idea was circulated in other national medical journals.

Due to the rapid increase in the circulation of $V d K$ in the summer of 1908, an increasing number of physicians formed an alliance in favor of Esperanto. Mikołajski presumably remembered his proposal from the previous year and again suggested the creation of an official association in July. ${ }^{23}$ In the following issue, which appeared only a few weeks before the upcoming congress in Dresden, Mikolajski's idea was elaborated by Róbin and presented to the subscribers. ${ }^{24}$ As the official representative of the Universal Esperanto Association in Warsaw, he approached the headquarters and suggested the creation of the federation. At the second meeting of the Medical group at the Dresden Congress, an association was founded with the name Tutmonda Esperanta Kuracista Asocio on August 21, 1908. From the report in the official congress records ${ }^{25}$ and a more detailed version of this report in $V d K,{ }^{26}$ the founding of TEKA appears to have been a mere formality. Only the discussion about the future of $V d K$ as an organ of the association was extensive, and the association to be founded was mentioned in the course of the discussion as a guarantee for the journal.

TEKA, as formulated in point 1 of its regulations, strived to promote "practical relations between Esperanto physicians of all countries." 27 The reports

\footnotetext{
22 Ibid.

23 Mikołajski, "Organizo de la kuracistoj-esperantistoj," 45-47.

24 Róbin, "Organizo de kuracistoj-esperantistoj," 63-64.

25 Zamenhof, "Kuracistoj," 145-48.

26 Krukovski, "IV. Kongreso Esperantista,” 82-86.

27 Zamenhof, "Kuracistoj," 146.
} 
of the president, Prof. Henri Dor from Lyon, and the secretary, Dr. Wilhelm Róbin from Warsaw, in the first official yearbook of 1909 explained further goals and working methods. Dor reported the hope that all larger cities and health resorts would have at least one TEKA contact person who would supply the local physicians with information. ${ }^{28}$ Róbin added contacts in university towns to the list. ${ }^{29} \mathrm{He}$ also mentioned the goal of propagating the language at the International Medical Congress in Budapest in 1909. For this purpose, an independent congress commission was formed, which had to demonstrate at the meetings in Budapest that it was possible "to hold a scientific speech and free discussions in Esperanto." ${ }^{30}$ As a final goal, Róbin added medical excursions to various health resorts, which were to take place before the Esperanto World Congress in Barcelona or the International Medical Congress in Budapest in 1909. ${ }^{31}$ The positions already mentioned were supplemented with the addition of two vice presidents and a treasurer. These individuals formed the Central Committee. Ludwik Zamenhof also belonged to the Committee as Honorary President, as did his brother Leon Zamenhof as Honorary Consul. ${ }^{32}$ Furthermore, TEKA had seven honorary members at the beginning. ${ }^{33}$ At the national level, TEKA had consuls for 19 countries, including representatives for non-sovereign states such as Algeria and Poland. As further contacts, official representatives in 38 cities are listed in the yearbook. ${ }^{34}$

The Central Committee and the other members developed their own organizational structure of consuls and representatives. In 1910, the year in which membership was at its largest, TEKA had consuls in 29 countries, including nonsovereign territories, such as Bohemia, Galicia, and the Polish part of Russia. ${ }^{35}$ Representatives were found in 115 different cities. ${ }^{36}$ The representatives and

\footnotetext{
28 Dor, "Al Sinjoro," 10.

29 Róbin, "Kion ni faris?" 15.

30 Ibid.

31 Ibid., 16.

32 In addition to Ludwik and Leon Zamenhof, their brothers Aleksander and Henryk were also active as doctors and members of TEKA. The brothers' involvement in TEKA differed in manner and scope: Ludwik attended meetings during the Esperanto Congresses as honorary president, but he did not hold executive positions. Leon was honorary consul of TEKA and wrote for $V d K$. Aleksander contributed to the journal Kuracisto in 1913. No particular involvement can be ascertained on the part of Henryk, nor can it be proven whether he was still a member of TEKA after 1910. T.E.K.A.-Jarlibro 1909, 41. See also: Wincewicz et al., "Language and medicine," 287-92.

33 T.E.K.A.-Jarlibro 1909, 19.

34 Ibid., 19-23.

35 T.E.K.A.-Jarlibro 1910, 13-15.

36 Ibid., 15-21.
} 
consuls had the task of collecting membership fees from the physicians in their regions and sending them to the treasurer. The representatives in health resorts were later highlighted separately, with the indication that doctors could send their patients there. In 1911, 18 representatives from health resorts were listed, most of which were located in German-speaking countries. ${ }^{37}$

Due to the financial hardships TEKA incurred in order to publish its own journal, membership classes were introduced in 1912. The TEKA membership fee in 1912 was 2 Spesmilo; ${ }^{38}$ an Esperanto currency where 1 Spesmilo was the equivalent of half a dollar, 2.50 Swiss francs, or one ruble. First, the category of so-called protectors was created, who paid 10 Spesmilo a year. ${ }^{39}$ By the end of 1912, 28 members of the TEKA had earned the title of protector through their fees. ${ }^{40}$ In 1913, 21 members received the rank. ${ }^{41}$ Despite the additional financial support from the protectors, the expenses in 1913 could only be covered with reserves from the previous year. The difference was around 600 Spesmilo, which was equivalent to 300 more membership fees. As the Executive Committee was aware that a doubling of membership was not feasible, further membership classes were introduced. In the form of a "grant fund," two further categories were introduced in addition to the protectors. The highest level became the patron, with an annual contribution of 30 Spesmilo, and the second highest level was the subventionist, with a contribution of 20 Spesmilo. In return, three issues of Kuracisto (Physician) were sent to the protectors, six to the subventionists, and 10 to the patrons for propaganda purposes. Furthermore, the groups of subventionists and patrons were given the right to elect their own TEKA vice president, who defended the interests of the journal in the Central Committee and cooperated with the editor-in-chief of Kuracisto. ${ }^{42}$ The last issue of Kuracisto before the war lists five patrons, two subventionists, and 22 protectors as of June 1914, which amounts to a further 410 Spesmilo in income and could have ensured Kuracisto's continued existence. ${ }^{43}$

37 "Alvokoj de la Komitato," 17.

38 The Spesmilo was an Esperanto currency where 1 Spesmilo was the equivalent of 0.5 US Dollar, 2.50 Swiss Francs, or 1 Russian Rouble. Within the Esperanto movement, international payments often took place via the Cekbanko Esperantista (Esperantist Cheque Bank), which undertook banking transactions with the Spesmilo in London from 1907 to 1917.

39 Róbin, "Kelkaj vortoj," 58.

40 Johnston, "Kasa Raporto," 48.

41 Ibid., 204.

42 Jameson Johnston, Śidlovskij and Weiss, "La centra komitato de T.E.K.A.," 203-4.

43 Alexander, "Kasa Raporto," 93. 


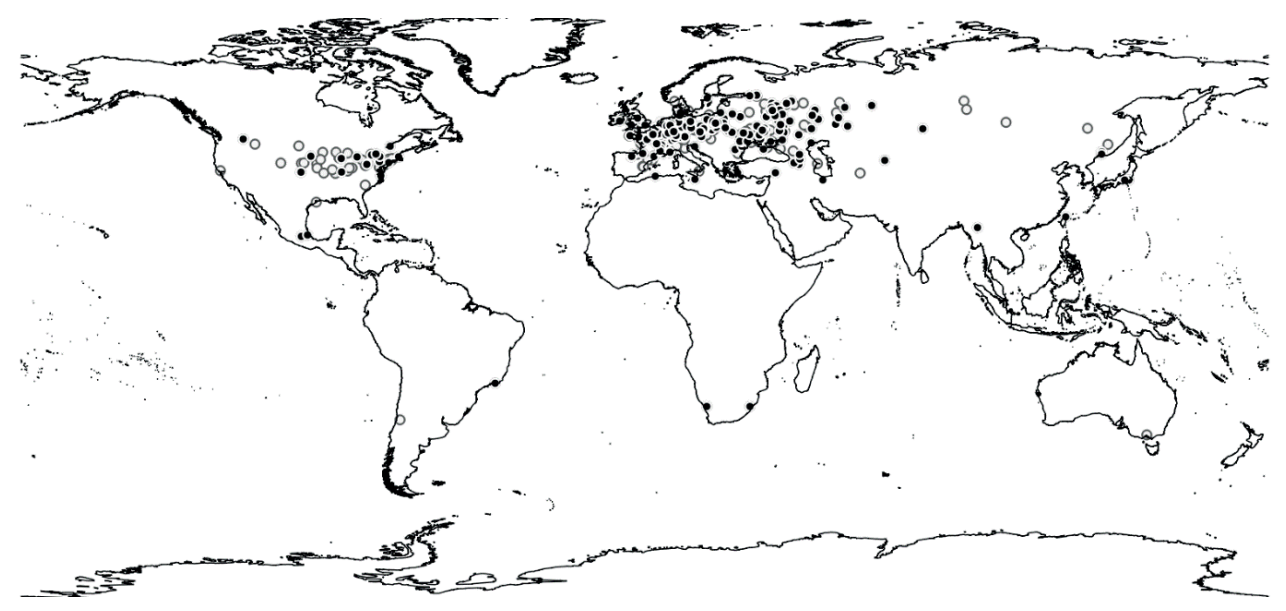

Map 1. TEKA members around the world in 1909 (black dots) and new members in 1910 (white dots).

From the outset, the geographical distribution of TEKA members had its main concentration in East Central Europe. ${ }^{44}$ One of the reasons for this was the fact that the first official TEKA journal, $V d K$, was based in Lviv and had reached both Polish and Russian Esperantists even before TEKA was founded. As an early Esperanto stronghold with many academic Esperantists, France was the second hotspot. From these centers, a strong propagation of the language took place after the foundation, which is reflected above all in the far reaches of Russia and North America. The subsequent period led to the opening up of new cities and their medical communities and also in increase in the number of

44 The map shown here is based on TEKA yearbooks from 1909 and 1910. The membership lists were converted into a database on the basis of which this map was made using Geographic Information Systems. I conducted my research at the Institute for Transnational and Spatial History at the University of St Andrews. Many scholars argue for the analysis of spaces and the use of transnational history as a point of view, and they support the use of maps and other visualizations. My broader project links these strands and applies them to technical methods in practice. By creating different maps, this work combines the concept of space with the perspective of transnational history. This is a novel blend of approaches and goes beyond previous methodical work and closes an existing gap in historical research. Based on membership lists, it is possible to link individuals with their places of residence and thereby represent the distribution within a town, a region, or globally. Despite the recent rise of interest in transnational spaces and networks, visualizations on this basis have never been done in this way for a historical movement. In a heuristic manner, the sparse information concerning names, addresses, and professions can result in extensive networks. Pierre-Yves Saunier also confirms this benefit, pointing out the importance of maps as historical tools. He argues that maps would help further understandings of the topographical dimension of flows in the world and that they unravel the intra-national process of centralization. Furthermore, maps can frame the analytical and narrative process and serve as an effective means of understanding and narration. See: Saunier, Transnational History, 126-27. 


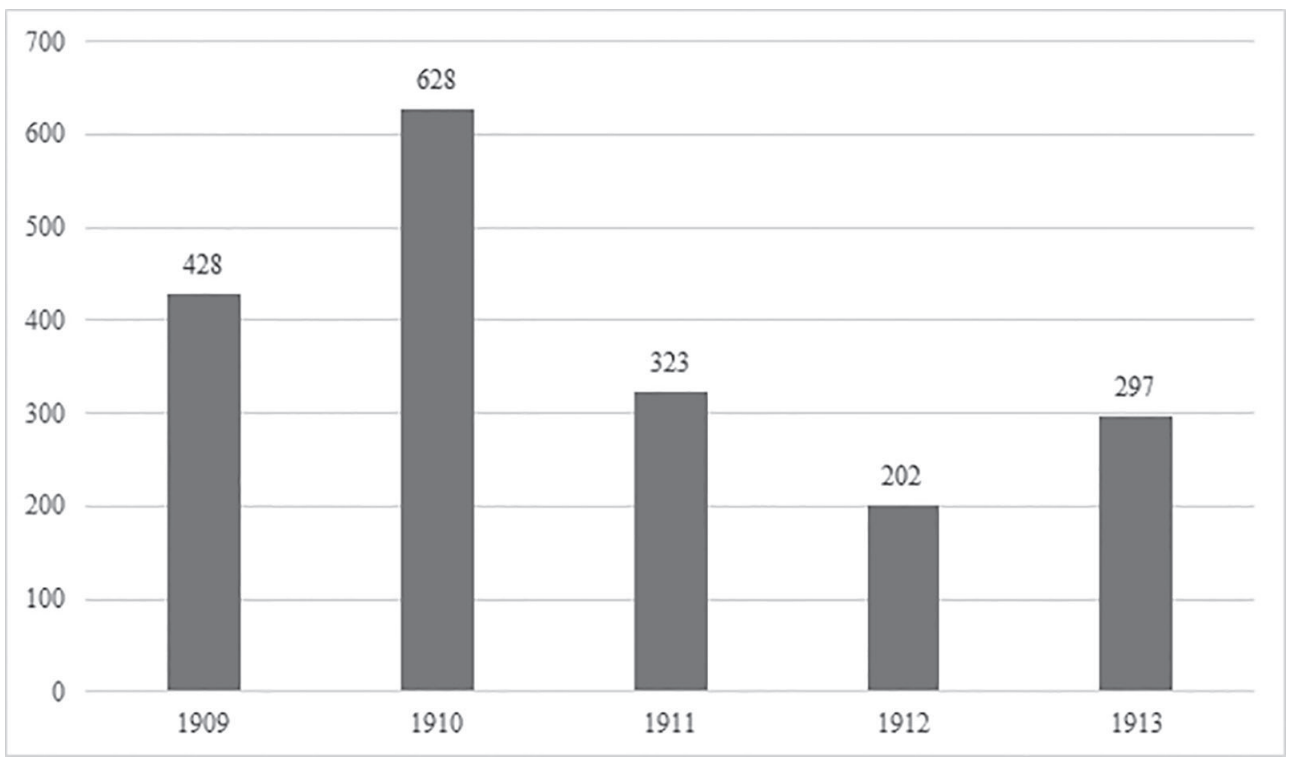

Table 1. Development of TEKA membership 1909-1913

TEKA members on the ground. Depending on the activity of the local group and the commitment of the members, the dissemination of TEKA varied. From Warsaw, the method of Wilhelm Róbin is known, who contacted all the Esperanto doctors he knew with the simple sentence: "If you want to subscribe to the newspaper, please sign your name on the list and pay one ruble." ${ }^{\prime 4}$ Almost all his colleagues signed, and this method was presented as an effective example at the TEKA meeting in Dresden. ${ }^{46}$

The membership development of TEKA can be traced through the official publications of the association. After the foundation in Dresden in August 1908, the first yearbook with an extensive list of members was published in spring 1909. Another yearbook was published for the year 1910, showing an increase of about 200 new members. A new yearbook with the membership list for 1911 was announced but never published. ${ }^{47}$ Therefore, for the following years, the list of paid members in the treasurer's reports is used to trace membership development. What is particularly striking about the overview is the rise towards 1910 and the drastic fall in the following year, which was caused by the discontinuation of $V d K$ as the official journal. The 1909 yearbook presented the membership figures shortly after the foundation of TEKA. In 1909, information about the

45 Krukovski, "IV. Kongreso Esperantista," 84.

46 Ibid.

47 “T.E.K.A.-Anaro,” 29. 
existence of the association spread worldwide. A decisive factor was the official organ of the association, $V d K$, which had been in existence since the spring of 1908 and had almost 800 subscribers in 1909. At the end of 1910, however, cooperation between TEKA and $V d K$ came to an end. At the beginning of 1911, the association had a new organ, but it was suspended after two issues. It was not until August 1911 that a new members' magazine was published. The Oficiala Bulteno de TEKA (Official Bulletin of TEKA) contains a critical report on membership development by Wilhelm Róbin, who was secretary at the time:

The activities of the TEKA Committee were paralyzed ${ }^{48}$ in 1911 in the full sense of the word. We did not propagate the Association because we could not do so due to the known major obstacles that occurred on the part of Dr. Th[alwitzer] (regarding the Oficiala Bulteno). We did not dare recruit new members and promise them regular delivery of the official organ... We experienced a terrible period. From all sides, complaints, protests, and just demands! [...]

The number of TEKA members is constantly growing, but unfortunately, this year we have lost many members who have been offended by the inaccuracy of our Internacia Medicino organ and by the stubborn silence of its publisher, who did not even respond to letters and prepaid telegrams. ${ }^{49}$

The publication of Internacia Medicino (International Medicine) under Adolf Thalwitzer as editor led to various problems. The first edition was published without proofreading and without TEKA's consent, resulting in several errors in quotations and mention of authors. Before the second issue, Thalwitzer had already received money in the amount of 186 membership fees for further publication, but he then no longer replied to letters from the committee, so cooperation between Thalwitzer and the TEKA was discontinued. ${ }^{50}$ Compensation for this long period of declining membership could only be made through the constant publication of the journal Kuracisto from 1912 onwards. For the year 1914, Kuracisto contains evidence of 215 membership subscriptions received; however, the journal ceased to exist in June 1914, so the complete membership figures for the year are not known.

The further general development of TEKA remained unchanged. In 1910, a separate TEKA Congress was held at the UEA Congress in Augsburg. ${ }^{51}$ The

48 Italicized in the original.

49 Róbin, "Raporto," 26.

50 “Cirkulero al T.E.K.A.-anoj," 1-3.

51 Ibid. 
official Esperanto World Congress took place in Washington. It was attended by only a few Europeans because of the long distance. In the period just before the outbreak of the war, TEKA congresses were held during the World Congresses, with frequent visits to local institutions and clinics. Two lines of development were of particular importance: first, the TEKA medical newsletter as a link among the members, and second, cooperation with the International Red Cross.

\section{Esperanto Medical Journals}

The Esperanto-speaking medical community urged for correspondence journals early on in order to present their national findings to an international audience through the multitude of different nations. The first medical articles were published in Internacia Scienca Revuo (International Science Review), a generic scientific journal in Esperanto which was published in Paris from 1904. The Parisian Esperantists noticed the lack of a medical journal and began to publish Internacia Revuo Medicina (International Medical Review, IRM) in 1906. ${ }^{52}$ This journal presented original articles in German, English, or French in one column and the respective translation in Esperanto in another column. Four issues of this journal were published that year before it ceased to exist. The editors' reports mentioned complaints about high subscription prices. Furthermore, it seemed that the desired number of subscribers and the general scope of the journal had not been achieved, as most of the articles were from French medical publications and thus French subscribers had little reason to subscribe. ${ }^{53}$ The IRM is mentioned in the dissertation by Pierre Corret about the adoption of an international auxiliary language in medicine. According to Corret, it failed due to the lack of an interested audience. ${ }^{54}$

Voco de Kuracistoj, ${ }^{55}$ on the other hand, was more successful and long-lived. This journal emerged from an existing Polish medical journal, Głos Lekarzy, which had already been successfully published in Lviv for several years. The editor, Dr Szczepan Mikołajski, ${ }^{56}$ initially planned only the introduction of an

52 Vallienne, Verax, "Nia programo," 1.

53 Corret, "Utilité et possibilité," 71.

54 Ibid.

55 All issues of $V d K$ have now been digitalized. The first volume is available in the online collection of the Austrian National Library. The other volumes can be found on the site of the Catalan Esperanto library Ramon Molera Pedrals.

56 Szczepan Mikołajski was a Polish physician from Krakow who was also active as a politician and journalist. Since 1902, he was working in Lviv, where he founded the journal Gtos Lekarsy, which he 
Esperanto section in his journal, but he was then encouraged by the high number of favorable responses to publish an independent journal. Two issues appeared in 1908 as free supplements, and from May 1908, the journal existed until its last issue in November 1911. Mikołajski also made use of the contributions from $V d K$ for his newspaper GL and published Polish translations. He thus enriched his journal with many international contributions. The first issue of $V d K$ from April 1908 was primarily aimed at Polish-speaking doctors, who had already been subscribers to GL. In an appeal to his fellow physicians, Mikołajski therefore formulated the aim of the journal to give Polish medicine and its achievements a proper forum, as it had hitherto been internationally underrepresented. ${ }^{57}$ Although the journal remained in publication for only about four years, it was one of the longest-lived Esperanto journals before World War I. Between 1908 and 1910, $V d K$ was the official organ of TEKA. However, as there were financial discrepancies in the forwarding of membership fees to $V d K$ editorial office throughout this period and TEKA refused to accept Mikołajski's new conditions, he resigned from publishing it as the official organ.

Mikołajski distinguished himself as an experienced publicist who had been publishing his Głos Lekaryy in parallel since 1903. The journals provided clear structures and, by listing the coauthors and subscribers, they allowed for a variety of investigations. The year 1909 is suitable as a focus of inquiry since it was the year in which the first complete volume was published and $V d K$ was the organ of TEKA for the entire year. The three areas that will be examined in more detail are: 1 . the subscribers to the journal, 2. the authors, and 3. the reviewed journals.

\section{Subscribers}

The distribution of subscribers can be visualized with the use of a map. ${ }^{58}$ In 1909, the magazine listed its subscribers. A total of 1,005 entries can be found,

\footnotetext{
published for twelve years. Furthermore, he worked as a journalist for different local and medical journals. It is not known when he became an Esperantist, but from 1907, he showed sympathy with the movement in his journal. From 1908 to 1911, he was a committee member of the Lviv Esperanto society and also their vice president. He served as a treasurer of TEKA in 1910 and was actively involved in the organizing committee of the Esperanto World Congress in Krakow in 1912. Pilch, "Mikołajski," 156-57; Golec, Stownik, 145-46.

57 "Do Kolegów Esperantystów," 6.

58 This map shows the subscribers to $V d K$ in 1909. Over the course of the year, the journal published extracts from the list of subscribers in each issue. I incorporated these entries into a database on the basis of which this map was created.
} 


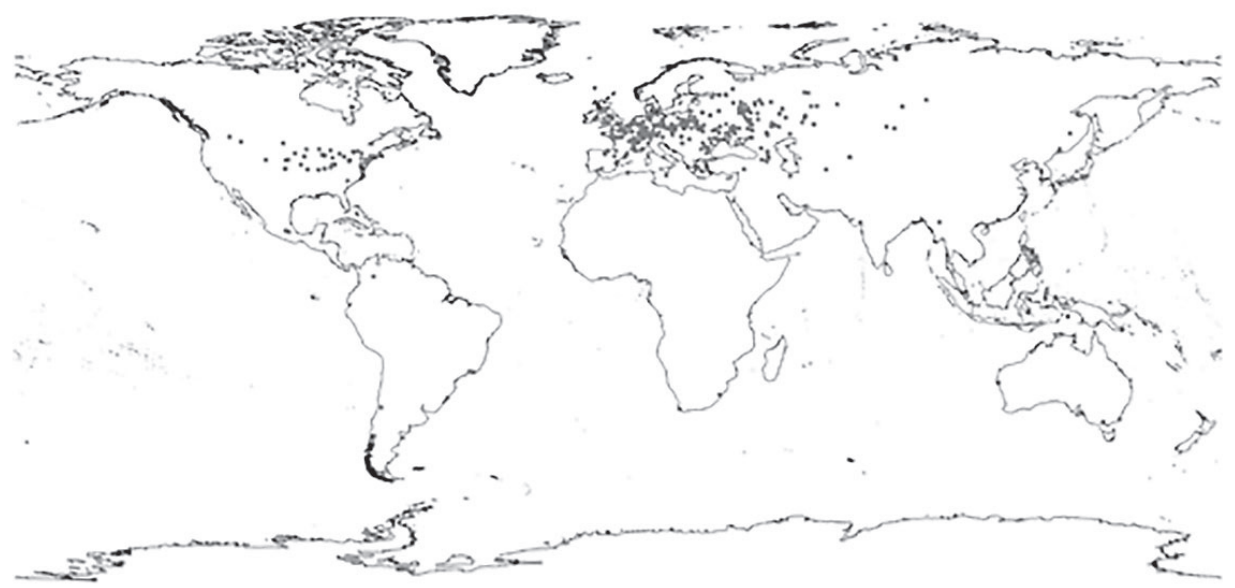

Map 2. Global distribution of $V d K$ subscribers in 1909

but there are repeated entries and orders for multiple journals to the addresses of Esperanto clubs. Adjusted for these factors, the number of subscribers was 770. The subscribers were be found in 367 different locations. The main focus was clearly in Europe and a broad strip in the north of the USA. When looking at the individual cities, Warsaw leads with a figure of 64 subscribers.

Table 2. Amount of $V d K$ subscribers in 1909 per city (more than 10) compared to TEKA members in 1909 and 1910

\begin{tabular}{|l|c|c|c|}
\hline \multicolumn{1}{|c|}{ Location } & $\begin{array}{c}\text { Number of } \\
\text { subscribers }\end{array}$ & $\begin{array}{c}\text { Number of TEKA } \\
\text { members } 1909^{1}\end{array}$ & $\begin{array}{c}\text { Number of TEKA } \\
\text { members } 1910^{2}\end{array}$ \\
\hline Warsaw & 64 & 56 & 53 \\
\hline Rio de Janeiro & 46 & 1 & 13 \\
\hline Moscow & 39 & 32 & 35 \\
\hline Lviv & 35 & 2 & 10 \\
\hline Berlin & 14 & 13 & 16 \\
\hline Dublin & 14 & 0 & 8 \\
\hline St Petersburg & 12 & 6 & 9 \\
\hline Budapest & 10 & 0 & \\
\hline
\end{tabular}

1 T.E.K.A.-Jarlibro 1909.

2 T.E.K.A.-Jarlibro 1910.

$V d K$ already benefitted from its function as an official TEKA organ in 1909. The 1909 TEKA Yearbook lists 428 members, which means that about 300 non-TEKA members belonged to the circle of subscribers. The comparison of subscribers and TEKA members shows that, in the cases of Rio de Janeiro, 
Dublin, and Budapest, many subscribers joined TEKA in 1909. However, it is not yet possible to explain how the high number of 46 subscribers in Rio de Janeiro was achieved. The high number of subscribers in Lviv probably correlates with the place of publication as well as the connection to Gtos Lekaryy as the predecessor journal. In Europe, there were many places where only one or a smaller group of subscribers was located. Larger accumulations were found in capitals such as Paris, Stockholm, Budapest, and Bucharest. Furthermore, no coherent clusters can be identified. The subscribers in the German Empire were relatively widely distributed. High subscriber numbers in Warsaw, Lviv, and Lodz provided a high absolute number of subscribers in Polish-speaking lands.

A cluster already noticeable in other visualizations, such as the World Congress participants, TEKA members, or publication sites of other Esperanto journals, can be identified north and along the 50th latitude. This connectivity belt ${ }^{59}$ stretched from Dublin via London, Belgium, northern France, and central Germany through Bohemia and the Polish-speaking lands into the Russian countryside and ended around Moscow, at a similar latitude to Dublin.

\section{Contributors}

The following table shows the most active collaborators of $V d K$ sorted by the number of their contributions in 1909. The high number of contributions is mainly due to scientific reviews of national novelties. The internist Izrael Fels, who, like Mikołajski, was based in Lviv and was already actively involved in Glos Lekaryy, ranks first. Fels frequently reviewed articles from Polish and German medical journals, but he also wrote reviews of English, Italian, French, and Russian publications in all disciplines; 97 of his articles were reviews and a correspondence. The large gap between Fels and L. Jenny is striking. With half as many contributions, the military physician Jenny submitted the second most articles. Jenny's contributions are exclusively reviews. He covered solely French medical journals but he dealt with all areas. In third place is the Russian physician V. Sobolev from Poltava, who contributed 36 reviews and one correspondence. Sobolev mainly covered Russian medical journals, and he also wrote on all fields. The places of residence of the authors listed here also correspond to the general distribution of the other contributors. Although there were also submissions

59 This term was invented by Dr. Bernhard Struck at a joint presentation on Up and Down the Scales. Visualising the Esperanto Movement around 1900 at the Digital Humanities seminar at the University of Manchester on February 27, 2020. 
from Australia, the Philippines, Japan, and the USA, the focus was clearly on East Central Europe and France.

Table 3. Contributors with more than 10 articles in 1909

\begin{tabular}{|l|l|c|}
\hline Author & Location & Contributions in 1909 \\
\hline Izrael Fels & Lviv, Habsburg Empire & 98 \\
\hline L. Jenny & Châlons-sur-Marne, France & 44 \\
\hline V. Sobolev & Poltava, Russian Empire & 37 \\
\hline René Badert & Tours, France & 18 \\
\hline Edmund Sós & Vienna, Habsburg Empire & 18 \\
\hline Wilhelm Róbin & Warsaw, Russian Empire & 13 \\
\hline S. Kanner & Galați, Romania & 11 \\
\hline
\end{tabular}

However, no first publications of medical findings took place in $V d K$. In addition to a review section, the journal mainly collected international submissions to surveys initiated by the editor Mikołajski. The surveys were about more general medical matters, such as medical secrecy or the right to Sunday rest. On the one hand, these surveys were passed on to national medical journals, ${ }^{60}$ but Mikołajski also used the submissions to enrich his Polish journal Gtos Lekaryy with international submissions.

Reviewed journals

The last unit of investigation to be considered is that of the reviewed journals. From Mikołajski's goals for $V d K$, it is clear that he wanted to give the internationally underrepresented Polish science a larger potential audience through his journal. It would therefore had been reasonable to assume that, alongside Polish medical journals, journals from other smaller countries would also be represented. However, the following overview shows that mainly Russian and German journals were used as sources for the reviews.

60 In 1911, a Survey on the Participation of Doctors in Duels was published, which found its way into French, German, Bohemian, Polish, Russian, and Spanish medical journals. Javier Guerrero, "Voĉoj de kuracistoj," Esperantaj Bitoj (blog) November 19, 2020, https://bibliotekoj.org/esperantajbitoj/vocoj-de-kuracistoj. html. 
Table 4. Overview of reviewed journals with more than 10 articles

\begin{tabular}{|l|l|c|}
\hline \multicolumn{1}{|c|}{ Journal } & \multicolumn{1}{|c|}{ Language } & $\begin{array}{c}\text { Number of articles } \\
\text { reviewed }\end{array}$ \\
\hline Vrachebnaya Gazeta (Saint Petersburg) & Russian & 42 \\
\hline Dentsche medizinische Wochenzeitschrift(Berlin) & German & 30 \\
\hline Khirurgiya (Moscow) & Russian & 16 \\
\hline Wiener Klinische Wochenschrift (Vienna) & German & 15 \\
\hline Medicinische Klinik (Berlin) & German & 11 \\
\hline Przeglad lekarski (Krakow) & Polish & 11 \\
\hline Russkiy vrach (Saint Petersburg) & Russian & 10 \\
\hline
\end{tabular}

Both the overview of the reviewed journals and the following overview of the source languages show that Mikołajski's goal was only partially achieved. German, French, and also Russian journal articles reflected the leading nations in medicine at the time, and they also corresponded to the backgrounds of the subscribers and contributors to the journal. However, the fact that Polish articles, of which there were 31, are ahead of English articles, of which there were 17 , shows an increase in publication, which can, admittedly, be explained by the small number of English-speaking contributors.

These three examples show the reach and influence of a small and young periodical from the province of Galicia. After one year, $V d K$ was able to build a functioning and coordinated editorial team. The two most important units, subscribers and contributors, were mainly based in East Central Europe, and their involvement with $V d K$ ensured the transfer of medical knowledge and the supply of national findings to a worldwide subscriber base. The analysis of $V d K$ exemplifies a platform for international medical cooperation. Although no medical discoveries were first published in $V d K$, the strength of the journal lay in the reviews of national findings. The coverage of German, French, and Russian articles made medical news from the countries which were leaders in medical research available to an international audience. The circulation of knowledge was successfully pursued in the medical journals of the Esperanto movement. However, it was mainly smaller nations that benefited from the reproduction of medical research in Esperanto. Since medicine, at least in Central Europe, was often dominated by English, French, and German before World War I, the journals served those who did not speak these languages themselves. 


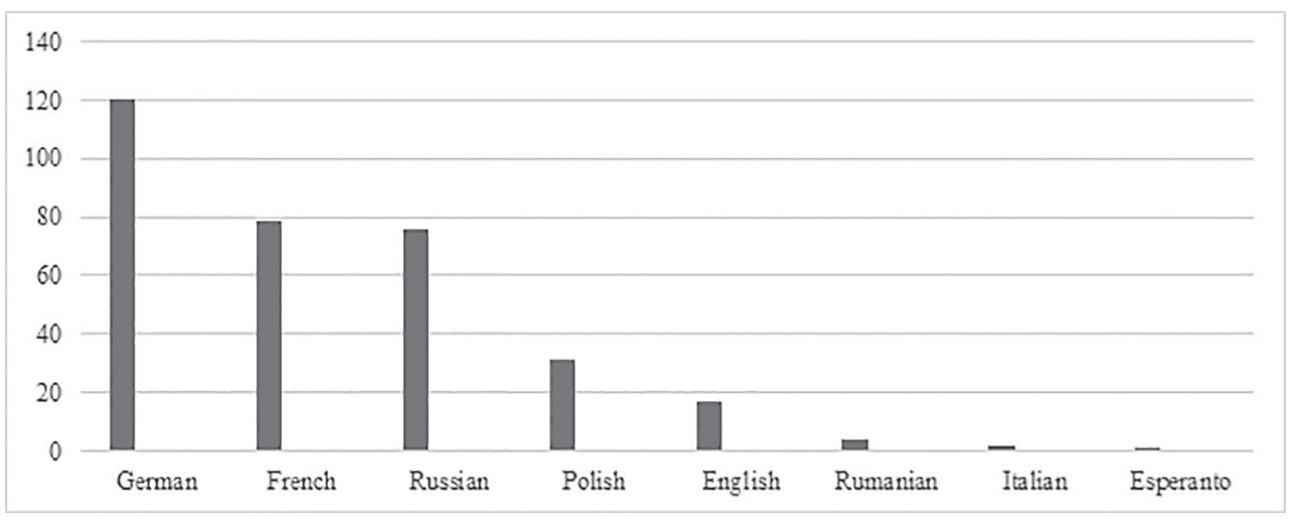

Table 5. Original languages of articles reviewed

After $V d K$ ceased to be the official organ of TEKA at the end of 1910, it was not until 1912 that a new medical journal in Esperanto was published. Internacia Medicino published two issues in 1911, followed by the Oficiala Bulteno de TEKA from 1911 to 1912, which served more as a newsletter of the association than as a medical journal. The journal Kuracisto, which was published in Warsaw from 1912 onwards, was the last prewar journal until the outbreak of war in 1914 and, like $V d K$, it was in the hands of Polish Esperanto doctors. After World War I, Internacia Medicina Revuo was published from 1923 onwards, and its successor, Medicina Internacia Revno, is today the official organ of the Universala Medicina Esperanto Asocio, TEKA's official successor organization.

\section{Esperanto and the Red Cross}

While the Polish Esperanto doctors were primarily involved in the work of the journal, cooperation with the Red Cross was largely in the hands of French Esperantists. ${ }^{61}$ The French Lieutenant Georges Bayol published a booklet in French on Esperanto and the Red Cross in 1906. In this book, Bayol described the necessity of an international language for the Red Cross. The book also contains basic information on the language and its structure, as well as vocabulary lists and possible conversations in French and Esperanto. ${ }^{62}$ Records of a gathering of Red Cross members at the international Esperanto congress in Geneva also exist

61 For overviews of Esperanto's role in the Red Cross, see: Sebert, "L’esperanto”; Hernández, “The Esperantist Movement's humanitarian activities"; Lavarenne, "Espéranto," 684-839.

62 Bayol, Espéranto et Croix-Rouge. Alongside the original French edition, the brochure has been translated into seven other languages. 
for the same year. ${ }^{63}$ Bayol spoke at the opening session of the Geneva congress on the introduction of the language within Red Cross societies, pointing out the great benefits of language in the societies. ${ }^{64}$ At the third working session, he addressed the issue again and proposed that Esperanto should be spoken by Red Cross members who were providing or receiving care. Furthermore, he appealed to the English Esperantists to put the Esperanto question on the agenda at the next International Red Cross Conference in London in 1907. ${ }^{65}$ The congress supported Bayol's proposal and published the following resolutions supporting the introduction of Esperanto within the Red Cross:

Considering that because of the variety of languages spoken by the wounded, sick, and nurses in war, the use of Esperanto would facilitate the care of the sick, The Congress expresses the wish that the subject of "The language Esperanto applied for Red Cross Services" be included in the program of the next International Conference of the Red Cross to be held in London in 1907 that one or more Esperantists discuss this subject at the London Conference; that very active propaganda be made for Esperanto in all societies helping those wounded in war. ${ }^{66}$

A discussion of this request at the London Red Cross Conference in 1907 did not take place, as the request was submitted too late. ${ }^{67}$ Nevertheless, the efforts of individual Red Cross societies to bring Esperanto into their associations did not stop. In 1908, the Société Française Espéranto-Croix-Rouge (French Esperanto-Red Cross Society, SFECR) was founded concurrently with TEKA. ${ }^{68}$ Starting with the 1908 World Congress in Dresden, maneuvers were carried out in cooperation with the local Red Cross as part of the congress program to demonstrate that basic medical care was possible in Esperanto. Among the participants were local volunteers, who had had to familiarize themselves with the language in the previous months, as well as congress participants and delegates of the Red Cross. The first of these maneuvers took place in Dresden and was continued in Barcelona and Antwerp in subsequent years. Representing the Red Cross at the Dresden Congress was Adolphe Moynier, son of Red Cross cofounder Gustave Moynier, who acknowledged the serious progress of the

63 Dua Universala Kongreso de Esperanto, 115.

64 Ibid., 16.

65 Ibid., 22-23.

66 Ibid., 29.

67 Sebert, "L'esperanto," 805. The draft proposal to the London Conference can be found ibid., 808-12.

68 Statuts et réglement intérieur. 
language and its uses in various fields. Furthermore, he was positively surprised that, in preparing a Red Cross maneuver, the organizers managed to teach the nurses enough Esperanto in ten lessons to enable them to follow instructions and answer questions. ${ }^{69}$

The procedure of such an Esperanto Red Cross maneuver is described in detail for the year 1909. During the Barcelona Congress, the participants in this maneuver consisted of members of the Spanish Red Cross and the international congress participants. After being transported to the casualty station, the wounded were questioned and examined by doctors and nurses. The diagnoses and personal data were noted on special cards in Esperanto. The next step involved transport to the field hospital, where the wounded were classified according to their diagnosis cards. The last step was the removal of the wounded. As a result, the exercise was perceived as positive by the whole group. According to the report, there were no difficulties in communication among the different nationalities. Due to the events of the Tragic Week ${ }^{70}$ in Barcelona in the forefront of the Congress, the language training of the Red Cross participants could only take place to a limited extent, but this was not noticed negatively during the exercise. At the Red Cross specialist meeting held during the Congress, the aspiration to introduce Esperanto to the organization was further discussed. The participants were convinced that the success of the exercise should be communicated. The report also indicated that some Red Cross groups had already offered Esperanto courses to their members. In addition, the Russian Red Cross had advised local committees to introduce courses on Esperanto. The US Secretary of War was also reported to have brought Esperanto to the attention of the National Red Cross. $^{71}$

At the 9th International Conference of the Red Cross in Washington in 1912, the Esperanto issue was successfully presented. Madame Lardin de Musset from the SFECR presented the advantages of using the language in the Red Cross and reported on successful applications in maneuvers during Esperanto congresses. The speech was supported by an Esperantist from Cuba, who reported on the success of Esperanto in his home country. As the proposal to introduce Esperanto in the Red Cross again had not been registered on the agenda, the conference leader announced that it would be forwarded to the

69 Moynier, "Raporto de la Internacia Komitato," 43-48.

70 The Tragic Week was a series of violent confrontations between the Spanish army and different groups, such as anarchists, socialists, and republicans from July 26 to August 2 in Barcelona.

71 Thalwitzer, "Esperanto kaj la Ruĝa Kruco," 46-51. 
Central Committee of the Red Cross. ${ }^{72}$ An official endorsement of the language was not offered by the Red Cross until a few years after the war. At the 10th International Conference of the Red Cross in 1921, a resolution was adopted that the national societies should encourage their members to learn Esperanto. ${ }^{73}$ The cooperation of the Esperanto movement with the Red Cross was welcomed by TEKA and mentioned in many places in its publications. However, it is noticeable that most of the supporters came directly from the French Red Cross and had mainly humanitarian backgrounds. As inventions of the same period, the Red Cross and Esperanto are among many other "idealistic internationalisms" the members of which have often been active in several movements, and their networks overlap in many places. ${ }^{74}$

\section{Conclusion}

TEKA was a typical internationally oriented association of its era. In a globalizing world, Esperanto-minded physicians from Europe were looking for an organization for international exchange. By founding an association, TEKA was able to extend its scope to various continents, especially with the help of medical journals in Esperanto, and it benefited from international meetings through the annual Esperanto World Congresses. TEKA also found its way into international medicine outside the Esperanto world and was presented in medical journals or at medical congresses as a solution to the language problem. Due to horrifying experiences of the war, the introduction of Esperanto into the Red Cross was an important concern. A few years before the outbreak of World War I, several initiatives to establish Esperanto officially as a language within the Red Cross failed. It was not until the tragic events of the war that the delegates voted in favor of the dissemination of Esperanto in the Red Cross in 1921. Though TEKA gave stimuli to the medical world in a few instances, it failed in its attempts to introduce Esperanto as a congress language at the International Medical Congresses in Budapest and London and as a language in the Red Cross. The strength was in providing medical information in Esperanto. This was reflected in the success of the journals and the resulting high number

72 Newième Conference internationale, 168-70.

73 Hernández, “The Esperantist Movement's Humanitarian Activities," 316.

74 John Hoberman describes these idealistic internationalisms in an article and refers especially to the personal overlap and participation in various international movements such as the Olympic Movement, Scouting, and Esperanto. Hoberman, "Toward a Theory." 
of subscribers during $V d K$ period. The attempt to continue the old heyday with and to compensate for the loss of many members was interrupted by the war.

\section{Bibliography}

Printed sources

Anonymous. "Alvokoj de la Komitato" [Appeal of the committee]. Oficiala Bulteno de T.E.K.A. 1, no. 1 (1911): 17.

Anonymous. "An International Language of Medicine." The British Medical Journal 1, no. 2249 (1904): 320-21.

Anonymous. "Cirkulero al T.E.K.A.-anoj" [Circular letter to TEKA members]. Oficiala Bulteno de T.E.K.A. 1, no. 1 (1911): 1-3.

Anonymous. "Do Kolegów Esperantystów" [To fellow Esperantist]. Gtos Lekarzyy 6, no. 8 (1908): 6.

Anonymous. "Esperanto." The British Medical Journal 2, no. 2746 (1913): 427.

Anonymous. "Seventeenth International Medical Congress." The British Medical Journal 2, no. 2744 (1913): 262-64.

Anonymous. "T.E.K.A.-Anaro" [TEKA Membership]. Internacia Medicino 1, no.1 (1911): 29.

Anonymous. "The International Medical Congress." The British Medical Journal 1, no. 2349 (1906): 33-35.

Anonymous. "The Sixteenth International Congress of Medicine." The British Medical Journal 2, no. 2543 (1909): 887-90.

Alexander, Robert. "Kasa Raporto, Por Aprilo 1914-a” [Cash report for April 1914]. Kuracisto 3, no. 6 (1914): 92-93.

Bayol, Georges. Espéranto et Croix-Rouge. Paris: Hachette, 1906.

Brzostowski, Aleksander Bolesław. Adresaro de Polaj Esperantistoj por 1909 [Addressbook of Polish Esperantists for 1909]. Warsaw: Jan Günther, 1909.

Dor, Henri. "Al Sinjoro D-ro Thalwitzer" [To Dr Thalwitzer]. In T.E.K.A.-Jarlibro 1909, edited by Tutmonda Esperanta Kuracista Asocio, 9-11. Kötzschenbroda-Dresden: H. F. Adolf Thalwitzer, 1909.

Dua Universala Kongreso de Esperanto [Second Universal Congress of Esperanto]. Edited by Esperantista Centra Oficejo. Paris: Esperantista Centra Oficejo, 1907.

Jameson Johnston, George, Konstantin Sidlovskij, and Karl Weiss. "La centra komitato de T.E.K.A. adresas al ciuj asocianoj sekvantan gravan sciigon" [The Central Committee of TEKA addresses to all associates following important notification]. Kuracisto 2, no. 10 (1913): 203-4. 
Johnston, George. “Kasa Raporto por Aŭgusto, Septembro kaj Oktobro 1913” [Cash report for August, September, and October 1913]. Kuracisto 2, no. 10 (1913): 204.

Johnston, George. "Kasa Raporto por Septembro kaj Oktobro 1912” [Cash report for September and October 1912]. Kuracisto 1, no. 3 (1912): 47-48.

Krukovski, Samuel. "IV. Kongreso Esperantista en Dresdeno” [IV. Esperantist Congress in Dresden]. Vocho de Kuracistoj 1, no. 8 (1908): 82-86.

Mikołajski, Szczepan. "Organizo de la kuracistoj-esperantistoj" [Organisation of Esperantist physicians]. Vocho de Kuracistoj 1, no. 5 (1908): 45-47.

Moynier, Adolphe. "Raporto de la Internacia Komitato de la Ruĝa Kruco pri la 4-a Kongreso de Esperanto" [Report of the International Committee of the Red Cross at the 4th Esperanto Congress]. In T.E.K.A.-Jarlibro 1909, edited by Tutmonda Esperanta Kuracista Asocio, 43-48. Kötzschenbroda-Dresden: H. F. Adolf Thalwitzer, 1909.

Neuvième Conférence Internationale de la Croix-Rouge. Edited by The American Red Cross. Washington: Judd \& Detweiler Inc., 1912.

Róbin, Wilhelm. "Kelkaj vortoj pri T.E.K.A" [Few words about TEKA]. Oficiala Bulteno de T.E.K.A. 1, no. 3 (1911): 53-58.

Róbin, Wilhelm. "Kion ni faris?” [What did we do?]. In T.E.K.A.-Jarlibro 1909, edited by Tutmonda Esperanta Kuracista Asocio, 12-16. Kötzschenbroda-Dresden: H. F. Adolf Thalwitzer, 1909.

Róbin, Wilhelm. "Organizo de kuracistoj-esperantistoj” [Organisation of Esperantist physicians]. Vocho de Kuracistoj 1, no. 6 (1908): 63-64.

Róbin, Wilhelm. "Raporto de la Sekretario" [Report of the Secretary]. Oficiala Bulteno de T.E.K.A. 1, no. 2 (1911): 26.

Rosenberg, Artur H. "Der Internationalismus in der Medizin und Esperanto." Medizinische Reform 18, no. 19 (1910): 202-4.

Sebert, Hippolyte. "L'esperanto et les Sociétés de la Croix-Rouge." Revue Internationale de la Croix-Rouge 3, no. 32 (1921): 803-14.

Sirjaev, Ivan. "Medicino" [Medicine]. In Enciklopedio de Esperanto [Encyclopedia of Esperanto], edited by Lajos Kökény, and Vilmos Bleier, 364-65. Budapest: Literatura Mondo, 1933.

Skałkowski, Bronisław, Izrael Fels, and Szczepan Mikołajski. "Odezwa do Lekarzy Esperantystów we wszystkich krajach" [Appeal to Esperantist physicians in all countries]. Gtos Lekaryy 21, no. 5 (1907): 4-5.

Statuts et réglement intérieur. Paris: Société Française Espéranto-Croix-Rouge, 1908.

T.E.K.A.-Jarlibro 1909. Edited by Tutmonda Esperanta Kuracista Asocio. Kötzschenbroda-Dresden: H. F. Adolf Thalwitzer, 1909. 
T.E.K.A.-Jarlibro 1910. Edited by Tutmonda Esperanta Kuracista Asocio. Kötzschenbroda-Dresden: H. F. Adolf Thalwitzer, 1910.

Thalwitzer, Friedrich. "Esperanto kaj la Ruĝa Kruco" [Esperanto and the Red Cross]. In T.E.K.A.-Jarlibro 1910, edited by Tutmonda Esperanta Kuracista Asocio, 46-51. Kötzschenbroda-Dresden: H. F. Adolf Thalwitzer, 1910.

Tria Universala Kongreso de Esperanto [Third Universal Congress of Esperanto]. Edited by Esperantista Centra Oficejo. Paris: Esperantista Centra Oficejo, 1908.

Vallienne, Henri, and Charles Verax. "Nia programo" [Our program]. Internacia Revuo Medicina 1, no. 1 (1906): 1.

Whitaker, E. T. “An Esperanto Society for Men.” The Lancet 2, no. 4287 (1905): 1292.

Zamenhof, Leon. "Kuracistoj" [Physicians]. In Kvara Universala Kongreso de Esperanto, edited by Esperantista Centra Oficejo, 145-48. Paris: Esperantista Centra Oficejo, 1909.

Zamenhof, Ludwik Lejzer [Dr Esperanto, pseud.]. Dr. Esperanto's International Language. Translated by Richard Henry Geoghegan. Warsaw, Samenhof, 1889. Originally published as Международныий язъи (Warsaw: Kelter, 1887).

Secondary literature

Corret, Pierre. "Utilité et possibilité de l'adoption d'une langue internationale auxiliaire en medicine." PhD diss., University of Paris, 1908.

Garvía, Roberto. Esperanto and Its Rivals: The Struggle for an International Language. Philadelphia: University of Philadelphia Press, 2015.

Geyer, Martin H., and Johannes Paulmann, eds., The Mechanics of Internationalism: Culture, Society, and Politics from the 1840s to the First World War. Oxford: Oxford University Press, 2001.

Guerrero, Javier. "Voĉoj de kuracistoj" [Voices of physicians]. Esperantaj Bitoj (blog) November 19, 2020, https://bibliotekoj.org/esperantajbitoj/vocoj-de-kuracistoj. html.

Golec, Józef. Stownik biografičny esperantystów polskich [Biographical dictionary of Polish Esperantists]. Cieszyn: Józef Golec, 2010.

Gordin, Michael D. Scientific Babel: How Science was done before and after Global English. Chicago: The University of Chicago Press, 2015.

Hernández, José María Rodríguez. “The Esperantist Movement’s humanitarian activities in the two World Wars and its relationship with the International Red Cross." International Review of the Red Cross 36, no. 312 (1996): 315-22.

Hoberman, John. "Toward a Theory of Olympic Internationalism." Journal of Sport History 22, no. 1 (1995): 1-37. 
Huber, Valeska. "Pandemics and the politics of difference: rewriting the history of internationalism through nineteenth-century cholera." Journal of Global History 15, no. 3 (2020): 394-407. doi: 10.1017/S1740022820000236.

Lavarenne, Christian. "Espéranto: L'idée interne dans ses origines et quelques-unes de ses expressions et manifestations (aide ou obstacle à la diffusion de la langue?).” PhD diss., University of Paris 13, 2012.

Saunier, Pierre-Yves. Transnational History. Basingstoke: Palgrave MacMillan, 2013.

Tonkin, Humphrey. "Invented cities, invented languages: Esperanto and urban textuality, 1888-1914." Language Problems \& Language Planning 40, no. 1 (2016): 85-99. doi: 10.1075/lplp.40.1.06ton.

Pilch, Andrzej. "Mikołajski." In Polski Stownik Biograficzny [ Polish biographical dictionary], vol. 21, edited by Sobiesław Mieroszewski, and Władysław Morsztyn, 156-57. Wrocław: Zakład Narodowy im. Ossolińskich, 1976.

Wincewicz, Andrzej, et al. "Language and medicine in the Zamenhof family." Acta Medico-Historica Adriatica 8, no. 2 (2010): 287-92. 